\title{
Controversial aspects about red date palm weevil
}

\author{
Hassan Y. Al Ayedh ${ }^{1}$ and Ahmed M. AlJber ${ }^{2}$ \\ (1) Life Science and Environment Research Institute, King Abdulaziz City for Science and technology, \\ Riyadh, Saudi Arabia, email: alayedh@kacst.edu.sa; (2) Department of Arid Land Agriculture, \\ College of Agricultural \& Food Sciences, King Faisal University, Hofuf, Saudi Arabia, email: aljabr@kfu.edu.sa
}

\begin{abstract}
Al Ayedh, H.Y. and A.M. AlJber. 2019. Controversial aspects about red date palm weevil. Arab Journal of Plant Protection, 37(2): 153-155.

This short note reviews and discuss three major red palm weevil (RPW) management controversies, mainly (i) the possibility of date palm fumigation by Aluminium phosphide, (ii) use of pheromone traps, and (iii) potential use of hyperspectral imaging for RPW detection. It also emphasizes the need for collaboration among various research groups working on red palm weevil management to develop effective methods to manage this pest.

Keywords: RPW, Control, management.
\end{abstract}

\section{Introduction}

Red palm weevil (RPW) Rhynchophorus ferrugineus (Olivier) (Coleoptera : Curculionidae) is indeed a global species infesting more than 30 palm species (Hussain et al., 2013b). Rhynchophorus weevil is the only species spread from its original home in South Asia and Southeast Asia to many geographical places in the world. The time frame of RPW spread was different as from early 80 s in the Gulf region until the year 2010 in California, USA.

Integrated pest management is the best solution for RPW suppression. However, invasion of RPW in different geographical regions over time raised numerous controversies regarding control options. Severity of the issue demands the development of a reliable method to successfully eradicate RPW infestations. Currently available red palm weevil management techniques, such as early detection, pheromone trapping, insecticide applications, quarantine and eradication of infested plants, face controversial and conflicting arguments not only from researchers in various disciplines, but also from farmers.

In this review, we have discussed three major RPW management controversies including 1) possibility of date palm fumigation by Aluminium phosphide; 2) pheromone trap usage; 3 ) potential of hyperspectral imaging for RPW detection.

\section{Fumigation by Aluminium Phosphide}

Aluminium phosphide is a cheap effective and commonly used pesticide (Gurjar et al., 2011), and is mainly used to protect stored products from infestation with insect pests. It is a poisonous chemical among agricultural pesticides. The fumigation process by using Aluminium phosphide occurs while a gas is liberated when it comes in contact with either atmospheric moisture or with hydrochloric acid in the stomach. In Saudi Arabia, few farmers started the use of Aluminium phosphide to control RPW infestations in the field. Unfortunately, farmers are using a very basic and simplified method for its application. In brief, they are using highly puncturable plastic wrapping around the infested date palm trunk after inserting aluminium phosphide tablets. According to their theory, the fumigant penetrate into the trunk throw the opening of the date palm and kill the RPW infestations.

Resistance to pesticides is the change of sensitivity of the pest to the pesticides, which will results in failure of insecticide ability to kill the pest. In this way, pesticides will be no longer affecting the pest. Resistance controlled by genes in the insects population and carried out through generations. Upon exposure of pest to insecticides will force the resistance gene to rise, creating more resistant insect populations. Insect life cycle plays an important role in resistance emergence. Insects with short life cycle are more likely to develop resistance (Siegwart et al., 2015), and help the resistance gene to be more affected. However, insect pests with longer life cycle will be less likely to develop resistance. The RPW life cycle is very long with two to three generations per annum (Abe et al., 2009; Hussain et al., 2013a, 2013b). Recently, a study from Pakistan reported 6379 folds of resistance ratios (RRs) for phosphine, which is astonishingly very high RR without any previously published scientific record about the use of Phosphine in their country (Wakil et al., 2018). Such results raises serious doubts and concerns about their suspicious findings. The methodology that was used, is generally practiced for stored grain pests. However, RPWs and stored grain pests are totally different and both require specific protocol for phosphine application. Surprisingly, they reported very high RRs from minor date palm growing areas instead of major date palm growing areas including Sindh and Baluchistan province of Pakistan. In this technological advanced era, such high RRs are lacking biochemical and molecular evidence for resistance development is not sufficient for such misleading claims. 
In another study, 8.72 RRs were calculated from RPW larvae fed on artificial diet incorporated with Cypermethrin in the Kingdom of Saudi Arabia (Al-Ayedh et al., 2016). This study was performed on RPWs populations collected from main date palm growing areas of the Kingdom of Saudi Arabia. In addition, RRs were dually supported with biochemical analysis. However, Wakil et al. (2018) reported very high RRs (73.82) for the same insecticide (Cypermethrin) against RPWs from minor date palm growing areas. Such controversial published results which lacked molecular or biochemical evidence is questionable.

The deeper insights of phosphine mode of action suggest that the phosphine has an inhibitory effect on insect respiratory system, therefore, the effect is quick (Bond, 1984). Under field conditions, the chances for the RPW populations to develop resistance are minimal due to long life cycle. In addition, phosphine application does not require frequent application and single application is required to control RPW infestation. In summary, resistance should be regarded as country specific issue due to country specific insect pest invasion history, severity of target pest population, and agro-ecosystem variations. Overall, Aluminium phosphide has great potential to control the infestations of RPWs within the palms. However, application of Aluminium phosphide at each step demands specialized protocol customized for RPWs management.

\section{Pheromone Traps}

Pheromone traps remains the focus of most research investigations during the last few decades (Ávalos and Soto, 2015; El-Shafie et al., 2011; Fiaboe et al., 2011; Hamidi et al., 2013; Hoddle et al., 2013; Miguens et al., 2011; Perez et al., 1996). Pheromone traps are being used in date palm plantations since 1990s. Monitoring, mass trapping and early detection are the main uses of the pheromone traps. Like other methods, pheromone trapping also have merits and some disadvantages. Pheromone traps successfully used in some parts of the world. However, there are some complaints that these traps also attracted red palm weevils and increased infestations in these areas. Such situations did not lead towards ignoring pheromone trapping. Overall, pheromone traps are an important monitoring and mass trapping tool, which can never be neglected in a RPW management program.

\section{RPW Detection}

The last issue is the utilization of new detection methods such as hyperspectral imaging (HI), which collects and processes information from across the electromagnetic spectrum (Bannari et al., 2016; Yones et al., 2014). The goal of hyperspectral imaging is to obtain the spectrum for each pixel in the image of a scene, with the purpose of finding objects, identifying materials, or detecting processes. Hyperspectral imaging, can detect the water stress reflection from the plant canopy (date palm tree canopy). The water stress in the canopy might occur because of phloem and Xylem water loss, or RPW infestation or some other factors. However, the main criticism made is that this technique detects the reflection of stress at very late stage of RPW infestation. Furthermore, it has become very difficult to distinguish images of water stress and RPW infestations. Therefore, this area of research demands further exploration and technical sophistications.

In conclusion, many arguments can be raised but the control application should be implemented with the support of scientific evidence. The collaboration among various research groups working on red palm weevil management can be helpful to develop effective methods against this pest.

\footnotetext{
الملخص

آل عائض، حسن يحيى وأحمد محمد الجبر. 2019. قضايا جدلية حول سوسة النخيل الحمراء. مجلة وقاية النبات العربية، 37(2): 153-153. تستعرض وتناقش هذه المذكّرة القصيرة ثلاثة خلافات رئيسةً حول إدارة سوسة النخيل الحمر اء؛ وتتركز أساساً حول: 1) إمكانية تدخين نخيل التمر باستعمال فوسفيد الألمنيوم، 2) استخدام المصائد الفيرمونية، 3) إمكانية استخدام التصوير فوق الطيفي للكشف عن سوسة النخيل الحمر اء. كما تشدّد على الحاجة للتعاون بين مختلف الفرق البحثية العاملة في مجال إدارة سوسة النخيل الحمر اء لتطوير طر ائق ناجعةً لإدارة هذه الآفة. كلمات مفتاحية: سوسة النخبل الحمر اء، مكافحة، إدارة الآفة.
}

\section{References}

Abe, F., K. Hata and K. Sone. 2009. Life history of the red palm weevil, Rhynchophorus ferrugineus (Coleoptera: Dryophtoridae), in Southern Japan. Florida Entomology, 92: 421-425. https://doi.org/10.1653/024.092.0302

Al-Ayedh, H., A. Hussain, M. Rizwan-ul-Haq and A.M. Al-Jabr. 2016. Status of insecticide resistance in fieldcollected populations of Rhynchophorus ferrugineus (Olivier) (Coleoptera: Curculionidae). International Journal of Agriculture and Biology, 18: 103-110. https://doi.org/10.17957/IJAB/15.0070
Ávalos, J.A. and A. Soto. 2015. Study of chromatic attraction of the red palm weevil, Rhynchophorus ferrugineus using bucket traps. Bulletin of Insectology, 68: 83-90.

Bannari, A., A.M.A. Mohamed and D.R. Peddle. 2016. Biophysiological spectral indices retrieval and statistical analysis for red palm weevil stressattack prediction using Worldview-3 data. Pages 3512-3515. In: 2016 IEEE International Geoscience and Remote Sensing Symposium (IGARSS). IEEE, Beijing, China. https://doi.org/10.1109/IGARSS.2016.7729908 
Bond, E. 1984. Manual of fumigation for insect control [WWW Document]. URL http://www.fao.org/docrep/X5042E/x5042E00.htm

El-Shafie, H.A.F., J.R. Faleiro, A.H. Al-Abbad, L. Stoltman and A. Mafra-Neto. 2011. Bait-Free attract and kill technology (Hook\&trade; RPW) to suppress red palm weevil, Rhynchophorus ferrugineus (Coleoptera: Curculionidae) in date Palm. Florida Entomology, 94: 774-778. https://doi.org/10.1653/024.094.0407

Fiaboe, K., R. Mankin, A. Roda, M. Kairo and C. Johanns. 2011. Pheromone-food-bait trap and acoustic surveys of Rhynchophorus ferrugineus (Coleoptera: Curculionidae) in Curacao. Florida Entomology, 94: 766-773. https://doi.org/10.1653/024.094.0406

Gurjar, M., A. Azim, A. Baronia and K. Sharma. 2011. Managing aluminum phosphide poisonings. Journal of. Emergencies, Trauma, and Shock, 4: 378. https://doi.org/10.4103/0974-2700.83868

Hamidi, R., D. Schmidt-Buesser, P. Couzi, B. Lherminier, K. Khfif, M. Renou, A. Avand-Faghih and D. Rochat. 2013. Olfactory trapping of red palm weevil: Bases, good practices, limits and prospects. Pages 261-272. In: AFPP-3e Conférence Sur l'entretien Des Zones Non Agricoles, Toulouse, France. Toulouse.

Hoddle, M., A.H. Al-Abbad, H. El-Shafie, J. Faleiro, A. Sallam and C. Hoddle. 2013. Assessing the impact of areawide pheromone trapping, pesticide applications, and eradication of infested date palms for Rhynchophorus ferrugineus (Coleoptera: Curculionidae) management in Al Ghowaybah, Saudi Arabia. Crop Protection, 53: 152-160. https://doi.org/10.1016/j.cropro.2013.07.010

Hussain, A., M. Rizwan-ul-haq and A.M. Al-Jabr. 2013a. Red palm weevil: Understanding the fungal disease mechanism and host defense. Pages 1278-1286. In: Microbial Pathogens and Strategies for Combating Them: Science, Technology and Education. Formatex Research Center, Badajoz, Spain.

Hussain, A., M. Rizwan-ul-haq, A.M. Al-jabr and H.Y. Al-Ayied. 2013b. Managing invasive populations of red palm weevil: A worldwide perspective. Journal of Food Agriculture and Environment, 11: 456-463.

Miguens, F.C., J.A.S. De Magalhães, L.M. Amorim and V.R. De Goebel. 2011. Mass trapping and biological control of Rhynchophorus palmarum L.: A hypothesis based on morphological evidences. EntomoBrasilis, 4: 49-55.

Perez, A., R. Hallett, A. Oehlschlager, J. Borden, G. Gries and R. Gries. 1996. Pheromone chirality of Asian Palm Weevils, Rhynchophorus ferrugineus (Oliv.) and R. vulneratus. Journal of Chemical Ecology, 22: 357368. https://doi.org/10.1007/BF02055104

Siegwart, M., B. Graillot, C. Blachere Lopez, S. Besse, M. Bardin, P.C. Nicot and M. Lopez-Ferber. 2015. Resistance to bio-insecticides or how to enhance their sustainability: a review. Frontiers in Plant Science, 6: 381. https://doi.org/10.3389/fpls.2015.00381

Wakil, W., M. Yasin, M.A. Qayyum, M.U. Ghazanfar, A.M. Al-Sadi, G.O. Bedford and Y.J. Kwon. 2018. Resistance to commonly used insecticides and phosphine fumigant in red palm weevil, Rhynchophorus ferrugineus (Olivier) in Pakistan. PLoS One, 13: e0192628. https://doi.org/10.1371/journal.pone.0192628

Yones, M.S., M.A. Aboelghar, M.A. El-Shirbeny, G. Khdry, A.M. Ali and N. Saleh. 2014. Hyperspectral indices for assessing damage by the red palm weevil Rhynchophorus ferrugineus (Coleoptera: Curculionidae) in date palms. International Journal Geosciences and Geomatics, 2: 16-23. 